\title{
5. PUNITIVE LAWS DURING PANDEMICS
}

InÊs Fernandes Godinho

\section{Introduction}

Punitive law is one of the instruments used by governments during pandemics as both a deterrent and a tool to repress behaviours that may jeopardize the public health. These new laws may be justified during the emergency, even if the same measures would be illegal or ultra vires if the government imposed the same measures at another time. This topic is presented following the path that illuminates the law previously written and currently in force, in addition to rules created in response to the pandemic in order to thereby identify and outline some trends in the use of punitive Law. We will primarily focus on Criminal Law, but also mention the Law applicable to Administrative Offences.

\section{Criminal Law}

\subsection{In force}

\section{- For Public Health protection}

In terms of existing Criminal legislation, articles 282 (Corruption of food or medicinal substances) and 283 (Propagation of disease and tampering of tests or prescriptions) of the Portuguese Criminal Code (hereinafter, CP, Código Penal, in Portuguese) can be mentioned. There may be doctrinal debate whether the legal interests protected by these 
criminal provisions are directly associated with public health (concept necessarily interpreted in the context of the pandemic ${ }^{1}$ ), being commonly understood that these laws aim to protect life and physical integrity $^{2}$. Nonetheless these criminal provisions have acquired front and center importance during in the pandemic emergency context ${ }^{3}$, and are inserted in the $\mathrm{CP}$ under the Title of crimes against life in society, in the Chapter which refers to crimes of common danger.

According to art. 282 of the CP:

1. Whoever

a) takes part in the use, production, confection, manufacture, packaging, transport, treatment, or otherwise engages in another activity that involves substances intended for the consumption (swallowed, chewed or drunk) by others for medical or surgical purposes, or engages in corrupting, falsifying, altering, reducing their nutritional or therapeutic value or adding ingredients to those substances; or

b) imports, conceals, sells, exhibits for sale, stocks for sale or, in any way, delivers for anothers' consumption, the substances subjected to any activity referred to in the previous subparagraph or that are used after the expiration date or are damaged, corrupted or altered by the course of time or other agents and to whose action they are exposed;

and thus creates danger to the life or physical integrity of another shall be punished by a term of imprisonment from one to eight years.

2. If the danger referred to in the previous paragraph is created by negligence, the agent shall be punished by a term of imprisonment up to five years.

3. If the conduct referred to in paragraph 1 is perpetrated with negligence, the agent is punishable shall be punished by a term of imprisonment of up to three years or a fine.

Article 282 of the CP sets forth penalties for corrupting medicinal or surgical substances, (so-called "Medicrime" of trafficking counterfeit

1 In Decree-Law no. 28/84, of January $20^{\text {th }}$, on anti-economic and public health violations, the only crime clearly oriented towards the protection of public health is clandestine slaughter (art. 22 of Decree-Law no. 28/84), which is clearly not adequate to the pandemic problem that serves as guidance for this work.

2 Cfr. J. M. Damião da Cunha, Anotação ao Art. 282º, in: Jorge de Figueiredo Dias (Dir.), Comentário Conimbricense do Código Penal, Tomo II, Coimbra: Coimbra Editora, 1999, p. 998 e s., p. 999; J. M. Damião da Cunha, Anotação ao Art. 283º, in: Jorge de Figueiredo Dias (Dir.), Comentário Conimbricense do Código Penal, Tomo II, Coimbra: Coimbra Editora, 1999, p. 1006 e s., p. 1007-1008.

3 These provisions are also included in other legal orders hereinafter analysed. 
or deliberately altered medicines) and may be especially important in light of its text as a roadmap for safely and fairly distributing vaccines for COVID-19.

Additionally: The Council of Europe Convention on Preventing Counterfeit Medicine and similar offenses involving threats to public health ("Medicrime Convention"4), opened to signature in October 2011, was ratified by Portugal in 2018. The Convention entered into force in the Portuguese legal system on April 1 $1^{\text {st }}, 2019$. Articles 5 to 9 of the Convention establish several obligations for ratifiying countries to criminalize the falsification and adulteration of medical products. Citing that a global problem of counterfeit or "fake" medicines and the reports of denatured malaria vaccines in Africa, the role of preventing counterfeit medicines clearly is a public health concern. It is noteworthy therefore first, the Convention has a broader range of application, when compared to article 282 of the CP: while the latter considers only medicinal substances for medical or surgical purposes - "substances that have diagnostic, prophylactic, therapeutic or anaesthetic virtues with scientific properties, in relation to human health" ${ }^{5}$ - the Convention's script includes both medical devices and accessories of such devices, which cannot be included in art. 282 of the $\mathrm{CP}^{6}$. The "counterfeiting" of a drug, when unrelated to a specific danger, has no criminal consequences, and only constitutes an administrative offence, within the scope of the Statute of Medication (in Portuguese, Estatuto do Medicamento, Decree-Law nr. 176/2006, of August 30 ${ }^{\text {th }}$ ), which, despite a recent change in 2019, has not been altered regarding this subject. As the Handbook for Parliamentarians for Ratification of the Convention points out, counterfeit medicine is a global threat to public health requiring a global response ${ }^{7}$.

${ }^{4}$ Ilise Feitshans, "Handbook for the Ratification of the Convention Preventing Counterfeit Medicines (Medicrime)" for the Council of Europe, presented at OECD Paris, France November 2015 published by the Secretariat of the Committee on Social Affairs, Health and Sustainable Development of the Parliamentary Assembly, the European Directorate for the Quality of Medicines and Health Care Council of Europe. 2015.

5 J. M. Damião da Cunha, Anotação ao Art. 282º p. 1000.

6 Susana Aires de SousA, A Convenção Medicrime do Conselho da Europa, Cadernos da Lex Medicinae n.o 4, Vol. II (2019), p. 465 e s., p. 469.

7 Council of Europe Press Release launching the report about the convention, held in OECD headquarters Paris November 2015: "The Convention against Medi- 


\section{According to Article 283 of the CP,}

1. Whoever:

a) Spreads contagious diseases;

b) As a doctor or his employee, nurse or laboratory employee, or person legally authorized to prepare an auxiliary examination or record of medical or surgical diagnosis or treatment, provides inaccurate data or results; or

c) As a pharmacist or pharmacy employee, supplies medicinal substances that do not comply with the prescription;

and thus creates danger to life or serious danger to the physical integrity of another person is punishable by imprisonment from one to eight years.

2. If the danger referred to in the preceding paragraph is created by negligence, the criminal agent shall be punished by a term of imprisonment of up to five years.

3. If the conduct referred to in paragraph 1 is perpetrated with negligence, the criminal agent shall be punished by a term of imprisonment of up to three years or a fine.

As for article 283 of the CP, it has deserved greater attention in view of the current pandemic situation ${ }^{8}$.

Indeed, contagious disease referred to in subparagraph a), must involve "serious" danger, cannot be applicable the myriad of every contagious disease that is not particularly serious. Nevertheless, "the article covers all types of diseases (regardless of whether their mandatory declaration is necessary, whether they are of known or unknown origin)

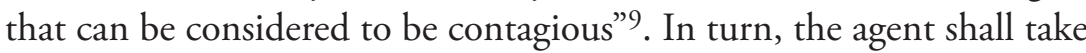
steps to prevent propagation of the disease, whether this spread occurs through transmission (in which the agent is himself a carrier of the

crime presents the rare opportunity for corporate pharmaceuticals, scientific researchers international law enforcement and human rights activists to work together to defend civil society against organized crime." stated Mme Claude Chirac of the Fondation Chirac, Paris, France. "Fake medicines not only hurt the unsuspecting patients who are victims of fake medicine and undermine public confidence in the integrity of healthcare delivery systems, but medicrimes also make profits that fuel efforts against governments and civil society by funding terrorism".

8 Maria Fernanda Palma immediately defended, in April 2020, that public health should be a legal good worthy of protection under the crime of disease propagation. Cfr. Maria Fernanda Palma, Propagação de doença contagiosa, disponível em: https:// cidpcc.wordpress.com/2020/04/10/propagacao-de-doenca-contagiosa-por-maria-fernanda-palma/.

9 Quoted from Cunha (1999), p. 1008 (Translated). 
disease), or by infection (in which the agent "contaminates" food/water or objects, etc). All human diseases and diseases common to humans and animals are under the scope of application of this article.

The Macau Special Administrative Region (Macao, S.A.R.), in its Criminal Code (hereinafter, CPM), also includes the criminalization of corrupted food or medicinal substances (art. 269 CPM), spreading disease, as well altering tests or prescriptions (art. $270 \mathrm{CPM}$ ); the latter two use identical wording as articles $282^{\circ}$ and $283^{\circ}$ of the CP (and inserted in the respective criminal codes following a similar order).

After the SARS health crisis of 2001-2003 however, Law no. 2/2004 (Law on prevention, control and treatment of infectious diseases) was approved in $\mathrm{Macao}^{10}$. This Law, aimed at guaranteeing public health and the effective prevention, control and treatment of infectious diseases (through the principles of priority prevention and appropriate treatment - art. 1/1), contains several measures that may be applicable in outbreaks, situations of rapidly increased numbers of infectious disease cases ("incidence") or in situations where there is a risk of outbreaks or risk of propagation of infectious disease (arts. 14, and 23 to 25). It establishes the crime of breach of preventive health measures as a tool to punish the violation of any imposed restrictive measures and for the violation of the filling in any required declarations (art. 10).

According to art. 30 of Law n. 2/2004:

Infringement of preventive health measure

The following penalties are applicable to (unless a more serious penalty is applicable under other legal provisions):

1) Whoever refuses to complete the declarations mentioned in subparagraph 1) of number 2 of article 10 or provides false data on those declarations to avoid the measures set out in this Law or otherwise refuse to undergo the medical examination referred to in subparagraph 3) of the same number, may be imprisoned for up to 6 months or punishable with a fine of up to 60 days;

2) Anyone who fails to comply with the measures mentioned in subparagraph 1) of number 1 of article 14, shall be punished by a term of imprisonment of up to 6 months or with a fine of up to 60 days;

10 For all see: Vera Lúcia Raposo, Macau, a Luta contra a COVID-19 no Olho do Furação, Cadernos Ibero-Americanos de Direito Sanitário 2020; 9(2): p. 12 e s. 
3) Whoever fails to comply with the measures mentioned in subparagraphs 2) or 3) of number 1 of article 14 shall be punished by a term of imprisonment of up to a year or with a fine of up to 120 days; and

4) Whoever fails to comply with the measures mentioned in paragraphs 1), 2) or 5) to 9) of number 1 of article 25, shall be punished by a term of imprisonment of up to 2 years or with a fine of up to 240 days.

In the new Criminal Code of Angola ${ }^{11}$ (hereinafter CPA) the crimes of adulteration of food and medicinal substances (art. 286) ${ }^{12}$ and the criminalization of the propagation of contagious disease (art. 287) are treated in a significantly different manner: although both crimes are included in the Title of crimes against collective security (specifically, in the Chapter dedicated to crimes of common danger), the crime set out in art. $287^{\circ} \mathrm{CPA}$ addresses only the propagation of disease, that is, the article does not mention, within the same crime, the alteration of tests or prescriptions. Another important difference is that the CPA specifically includes the crime of transmission of serious illness (art. 206) in the Chapter of placing people in danger, under the Title of crimes against people.

According to art. 206 of CPA:

1. Whoever, with the intention of transmitting a serious illness from which he / she suffers performs an act which is susceptible of infecting another person shall be punished by a term of imprisonment of up to 3 years or a fine of up to 360 days.

2. If the disease is transmitted, the penalty of imprisonment applicable is from 6 to 10 years.

The situation in Brazil is even more specific. Indeed, within the Brazilian Criminal Code (hereinafter, CPB), we can find a Chapter related to crimes against public health within the scope of the Title of crimes against public safety (arts. 267 and ff). Yet, although the Code sets forth the crime of counterfeiting, corrupting, adulterating or altering a product intended for therapeutic or medicinal purposes (art. 273 $\mathrm{CPB})$, this law is part of the specific Chapter related to crimes against public health, crimes directly related to epidemic situations, which are the crime of epidemic (art. 2670 CPB), the crime of infraction of

11 Approved by Law no. 38/20, November $11^{\text {th }}, 2020$.

12 In the Mozambican Penal Code, the equivalent crime only refers to food items. 
preventive sanitary measure (art. $268^{\circ} \mathrm{CPB}$ ) and the crime of omission of disease notification (art. 269 $\mathrm{CPB}$ ).

Epidemic

Art. 267 - To cause an epidemic, through the spread of pathogenic germs: Penalty - imprisonment, from ten to fifteen years.

$\$ 1$ - If death results from the crime, the penalty is applied in double $\$ 2$ - In the case of guilt, the penalty is imprisonment from one to two years, or, in the event that the death of the victim results from the crime, from two to four years.

Infringement of preventive health measure

Art. 268 - Infringing a decision from the public authorities, aimed at preventing the introduction or propagation of a contagious disease:

Penalty - imprisonment, from one month to one year, and fine.

The penalty is increased by one third, if the criminal is a public health worker or is a doctor, pharmacist, dentist or nurse.

Omission of disease notification

Art. 269 - The doctor who does not report to the public authority a disease whose notification is mandatory:

Penalty - imprisonment, from six months to two years, and a fine.

The crime of infringement of a preventive sanitary measure, as it results from its typical wording ("infringing a decision from the public authority"), is a blank criminal rule, and requires further specifications ${ }^{13}$.

\section{- Other crimes}

One of the crimes which also is problematic and widely manifest during pandemics is the crime of disobedience, set out in art. 348 of the CP and again in art. 7 of Law no. 44/86, of September 30 ${ }^{\text {th }}$ (State of Siege and State of Emergency Regime, hereinafter RESEE, in Portuguese: Regime do estado de sitio e do estado de emergência).

13 Which followed suit through Law 13.979/2020, regarding isolation and quarantine, and Decree (Portaria) no. 356/2020, by the Ministry of Health, as well as the Interministerial Decree (Portaria Interministerial) no. 5/2020, by the Ministries of Justice, Public Safety and Health. 
At the beginning of the state of emergency in Portugal, Decree No. 2-A/2020, of March 20 th 14 , established a specific crime of disobedience applicable to cases of violation of the obligation of mandatory confinement (art. 3). Additionally punishable with this crime of disobedience (art. $348 \mathrm{CP}$ ) was a set of other situations, such as failure to close facilities and establishments or suspend retail commerce or service provision (art. 32/1/b) of the Decree). This model was maintained by Decree no. 2-B/2020, of 2 April (arts. 3 and 43/1/d)); and Decree no. 2-C / 2020, of 17 April (arts. 3 and 46/1/d)). Decree no. 2-D/2020, of April $20^{\text {th }}$ set out the crime of simple disobedience, applicable to citizens for the violation of prohibition of circulation between May $1^{\text {st }}$ and $3^{\text {rd }}, 2020$, a period in which Portugal had already decreed the state of calamity (art. 3). Subsequently, the new state of emergency declaration, in Portugal on November $6^{\text {th }} 2020$, the crime of specific disobedience (set out in the above mentioned Decrees no. 2-A, 2-B and 2-C) was substituted by the crime of disobedience (art.12/1/b) of Decree no. 8/2020, of 8 November), a measure that would be maintained in the following state of emergency decrees enacted by the President of the Republic (Decree no. 9/2020, November $21^{\text {st }}$ [art. 50] and Decree no. 11/2020, of 6 December [art. 58]). Under this construct, the crime of disobedience is fundamentally linked to the violation of mandatory confinement, to the violation of the ban on driving on public roads and to the violation of the limitation of the activities of commercial establishments and services.

The crime of disobedience is also found in art. 312 CPM, art. 330 $\mathrm{CPB}$, art. $340 \mathrm{CPA}$ or in art. 353 of the Penal Code of Mozambique.

By contrast to a specific regime in the Macao Special Administrative Region, resorting to the crime of disobedience, following the options adopted in the Portuguese legal system is not necessary. In countries where there is nothing similar to Law No. 2/2004 in force in Macao. S.A.R, the use of this repressive approach - even when there are clearly articulated specific crimes for the protection of public health - has been the path followed as a way of sanctioning the violation of sanitary measures imposed in the control and fight against COVID-19.

14 Which regulated the first declaration of the state of emergency (decreed by the President of the Republic's Decree no. 14-A/2020, March $18^{\text {th }}$ ). 
- Crimes applicable to vaccination fraud (violation of the vaccination plan)

Since the vaccination process is already underway, benefiting oneself or a third party may result in the perpetrator being charged for the crime of abuse of power or the crime of undue receipt of an advantage, if the perpetrator adopts fraudulent conduct, designed to anticipate the inoculation and violate the adopted Vaccination Plan.

\subsection{Special}

As stated above, most legal systems already had crimes related to public health or the crime of disobedience.

However, it is possible to point out the case of the specific crime of disobedience for the violation of mandatory confinement (initially introduced by art. 3 of Decree no. 2-A/2020, of March 20 th , which has been removed and integrated in the crime of disobedience set out in art. 348 of the $\mathrm{CP}^{15}$.

\section{Other punitive legislation}

\subsection{Administrative infractions}

The administrative offense regime for calamity, contingency and alert situations ${ }^{16}$ is established by Decree-Law no. 28-B/2020, of 26 June ${ }^{17}$, aimed at "the creation of a sanctioning regime that ensures scrupulous compliance by the population with the measures that are indispensable to contain the infection".

In structural terms, the law establishes a set of duties - from mandatory use of the mask, to the rules of maximum occupancy in venues and rules for physical distancing - in its art. 2, providing, later, in art. 3, the fines for non-compliance with the duties listed in art. 2.

Currently, violating most duties is sanctioned with a fine of 100 to 500 euros for natural persons and 1000 to 10000 euros for legal

15 And in the RESEE, regarding its scope of application.

16 Declared by Law no. 27/2006, of July $3^{\text {rd }}$ (Framework Law for Civil Protection).

17 Which has been altered five times, the last of which by Decree-Law no. $8-A / 2021$, January $22^{\text {nd }}$. 
persons, being the fine amount doubled during the state of emergency (art. 3-A). The amount of the fine is increased in the event of non-compliance with rules applicable to air traffic and airports.

\section{Tendencies}

There are two key trends regarding sanctions:

1. use of the crime of disobedience as the main criminal repressive tool for the cases of violation of sanitary measures, especially in countries that have resorted to exceptional regimes.

2. imposition of compliance with the sanitary measures has been achieved through the non-criminal path of applying administrative and civil sanctions. In Portugal, for example, recourse to the crime of disobedience continues to exist, but the prolonged health crisis led to approval of a specific administrative regime to ensure that the population observed the imposed measures (Decree-Law no. 28- B / 2020, of 26 June).

\section{Application}

In terms of relevance, the crime of disobedience has been, in criminal terms, the criminal law format that has been most widely applied from the outset as a a basis for arresting disobedient people. As an illustration, note that between the beginning of the pandemic, in March 2020, and January 2021, Portuguese Public Security Police made 438 arrests for disobedience, when carrying out the inspection of the restrictive measures imposed by the Government in the fight against COVID-19 ${ }^{18}$.

The crime of specific disobedience created at the beginning of the pandemic by Decree No. 2-A/2020, of 20 March - was quickly criticized $^{19}$. It was declared unconstitutional (organic unconstitutionality) by the Court of Appeal of Guimarães, in a judgment from November

18 As it was reported by RTP: https:/www.rtp.pt/noticias/pais/psp-fez-438-detencoes-em-portugal-desde-marco-por-violacao-de-regras-de-confinamento_n1290209.

19 Alexandre Au-Yong Oliverra et al., Jurisdição Penal e Processual Penal, in: CEJ (Org.), Estado de Emergência - COVID-19 - Implicaçôes na Justiça, Lisboa, 2020, p. 429 e s., p. 432 e s. 
$9^{\text {th }}, 2020^{20}$. The decision states that because creating crimes is a matter of relative reserve of competence of the Assembly of the Republic, under article 165/1/c), of the Constitution of the Portuguese Republic, the aforementioned Decree no. 2-A/2020, of March 20 th, "when defining a new type of crime, invades the legislative competence that does not belong to it, which determines that no. 2 of art. 3 of the aforementioned Decree is damaged by organic unconstitutionality". Thus, a criminal rule - such as is the crime of disobedience in question in the Decree - must take the form of a law ${ }^{21}$. Furthermore, RESEE makes it clear, in its art. 19, no. 7, that the state of emergency cannot call into question the constitutional rules regarding the competence and functioning of the sovereign bodies. Thus, the Decree No. 2-A/2020, of March $20^{\text {th }}$, could not, as it did, have created a specific crime of disobedience. Reason, moreover, why the Government ceased to set out the specific disobedience crime in the subsequent Decrees.

This issue is illustrative of a more repressive initial trend, which has since then subsided, following the creation of the administrative regime of Decree-Law no. 28-B/2020, of June $26^{\text {th }}$.

\section{Main conclusions}

Concerning the criminal law currently in force, such as the Criminal Code, there exists a striking similarity between the different countries and the Macao, S.A.R. regarding the crimes of corruption of medicinal substances and the spread of disease. In addition, these crimes are generally classified as crimes of common danger, not specifically threatening public health. CPB's situation is different, because it has a chapter dedicated to crimes against public health, that lists types of crime specifically geared to epidemic and pandemic situations. It should

20 Disponível em: http://www.dgsi.pt/jtrg.nsf/86c25a698e4e7cb7802579ec004d3832/4bf68cafb74dfa02802-58639005815e9?OpenDocument.

21 Restriction applicable to both Laws enacted by the Assembleia da República (Parliament) or authorized Decree-Laws enacted by the Government (article 165\%/1/c) of the Constitution of the Republic of Portugal). Cfr. José de Faria Costa, Direito Penal, Lisboa: Imprensa Nacional casa da Moeda, 2017, p. $138^{\circ}$ e s.; Specifically regarding this Decree, see: Alexandra VIlela, COVID-19 e o Direito Penal, in: Inês Fernandes Godinho/Miguel Osório de Castro (Eds.), COVID 19 e o Direito, Lisboa: Ediçôes Universitárias Lusófonas, 2020, p. 127 e s., p. 134. 
also be noted the crime contained in art. 30 of Law no. 2/2004 in force in Macao specifically addresses these situations.

Another very interesting point, in terms of criminal law, is the use, by default, of the crime of disobedience, as a way of repressing disrespect to measures adopted to prevent and combat the pandemic. In fact, in countries not equipped with a law like Macao's Law No. 2/2004, states of exception - for example, states of emergency - have been used and the crime of disobedience is a commonly used tool to sanction the different violations of duties imposed on citizens, significantly increasing the relevance and impact of this form of criminalization in a pandemic context.

Despite its insertion in the CP having been originally contested ${ }^{22}$, it is nevertheless clear that the repressive path initially accentuated in Portugal - with the creation of a specific crime of disobedience - raises the veil over the dangers of resorting to states of exception ${ }^{23}$.

Using the Macao S.A.R. regime as a point of reference, the advantages over the use of other regulations and the necessity of adopting a better punitive framework for public health crises caused by epidemics or health pandemics should be emphasized, as heightened preparedness for pandemics is increasingly important in the future.

22 Cfr. Cristina Líbano Monteiro, Anotação ao Art. 348º, in: Jorge de Figueiredo Dias (Dir.), Comentário Conimbricense do Código Penal, Tomo III, Coimbra: Coimbra Editora, 2001, p. 349 e s., p. 350; Alexandra VILELA (2020), p. 133.

23 Even though it is clear that in the context of the RESEE the principle of Separation of Powers may never be jeopardized. 